Галушкіна Т. П., д.е.н., професор (Державна екологічна академія післядипломної освіти та управління, м. Київ), Жемба А. Й., к.е.н., доцент (Національний університет водного господарства та природокористування, м. Рівне), Серницька К. В., аспірант (Державний екологічний університет, м. Одеса)

\title{
ЕКОЛОГІЧНА ПОЛІТИКА УКРАЇНИ В КОНТЕКСТІ ГЛОБАЛЬНИХ КЛІМАТИЧНИХ ВИКЛИКІВ
}

В статті розглядаються напрями вдосконалення екологічної політики у відповідності до міжнародного законодавства та сучасних глобальних викликів. Обґрунтовано, що впровадження екологобезпечних заходів повинно сформувати сталу економічну систему, орієнтовану на забезпечення «зеленого» вектору розвитку економіки країни та її регіонів з врахуванням глобальних кліматичних змін. Доведено, що на сучасному етапі важливо забезпечити максимально повну реалізацію економічного потенціалу держави на шляху імплементації міжнародних вимог, що можливо лише за рахунок реалізації курсу «зеленої» економіки на всіх ієрархічних рівнях.

Ключові слова: екологічна політика, зелена економіка, екологічні та кліматичні зміни, екосистемний підхід, екологічне управління.

Постановка проблеми. Аналіз екологічної політики України стосовно створення екологічних передумов «зеленого» курсу розвитку держави є складним завданням, оскільки потребує врахування багатьох факторів та проведення одночасного аналізу нормативноправових та інституціональних засад втілення екологічної політики, з одного боку, й оцінки антропогенного навантаження за напрямами господарської діяльності та основними складовими навколишнього середовища (атмосферного повітря, грунтів, водного середовища, біо- та ландшафтного різноманіття, лісів), - $з$ іншого.

Државна екологічна політика України як частина реформ, що впроваджуються в процесі реалізації Угоди Україна-ЄС, визначається Законом Україні «Про основні засади (Стратегію) державної екологічної політики на період до 2030 року, де визначено конкретні заходи поетапного досягнення стабілізації і поліпшення стану довкілля України, забезпечення безпечного та комфортного середовища для життя та здоров'я населення, впровадження екологічно збалансованої системи природокористування. 
Суть цієї реформи полягає в інтеграції екологічної політики до політик соціально-економічного розвитку національного, регіонального та місцевого рівнів, а також до політик розвитку секторів економіки, з метою більш ефективного захисту навколишнього природного середовища та раціонального використання природних ресурсів України згідно міжнародних стандартів.

Після старту екологічної програми ООН під назвою «ніціатива «зеленої» економіки» (Green Economy Initiative) концепція «зеленої економіки» стала загальноприйнятою. Одним з перших результатів «Ініціативи «зеленої» економіки» став розроблений «Глобальний «зелений» новий курс», загальні цілі та завдання якого повинні сприяти багато стороннім і національним зусиллям, спрямованим на вирішення проблем, пов'язаних з глобальним кліматом, продовольством, паливом і водними ресурсами.

Аналіз останніх досліджень та публікацій. Фундаментальні дослідження розвитку моделі «зеленого» зростання повинні бути підґрунтям для розбудови державної економічної системи України, що, за словами Президента НАН України академіка НАН України Патона Б.Є., сприяє «розв'язанню гострої для України проблеми запровадження принципів «глобального зеленого курсу» в модель економічного розвитку України» [1]. Це підтверджено рішенням Постанови НАН України (№ 114 від 30.05.2012) про доцільність наукових розробок у цьому напрямі та початок асигнування з Державного бюджету цих фундаментальних досліджень.

Про орієнтацію державного курсу на «озеленення» економіки свідчить Національна доповідь «Цілі сталого розвитку: Україна» [2], яка декларує принципи «зеленої» економіки на державному рівні та розроблений в 2013 р. Міністерством економічного розвитку та торгівлі України проект плану заходів України у виконанні рішень та рекомендацій Конференції ООН з питань сталого розвитку «Ріо+20», де окремо виділено підготовку Концепції державної політики розвитку «зеленої економіки» (на виконанні рішень та рекомендацій Конференції ООН з питань сталого розвитку «Ріо+20»).

Оцінка законодавчо-нормативних передумов розвитку «зеленої» економіки в Україні позитивно схвалена та включена до Регіонального огляду перспектив розвитку країн-членів Організації Чорноморського Економічного Співробітництва (ОЧЕС) та ЮНЕП. Вагому допомогу Україні в цьому напрямі надають декілька міжнародних організацій через нову програму «Екологізація економіки в країнах Східного партнерства Європейського Союзу», яка виконувалась упродовж 2013-2016 рр., а саме Європейський Союз, Організація економічного співробітництва та розвитку, а також ООН (ЮНЕП та 
ЮНІДО), які мають значний досвід у реалізації політики ресурсоефективного «зеленого» зростання. $Є$ й інші міжнародні організації, зацікавлені допомогти Україні перетворитися на більш конкурентну та «зелену» країну.

Проведені фундаментальні дослідження свідчать, що на шляху реалізації концепції сталого просторового розвитку домінантою виступає ідея інтегрального підходу до вирішення економічних, соціальних та екологічних проблем [3]. Однак, визначено, що в Україні необхідність розроблення та впровадження політики «зеленого» зростання була викликана саме потребою екологізації економіки країни. Тому з 2016 року інклюзивний процес визначення завдань Національних цілей сталого розвитку до 2030 року відбувається за чотирма напрямами: справедливий соціальний розвиток; стале економічне зростання та зайнятість; ефективне управління; екологічна рівновага та розбудова стійкості. Як свідчать заявлені вже стратегічні вектори, суспільне бачення розвитку України до 2030 року охоплює такі орієнтири для досягнення, як добробут та здоров'я населення на основі інноваційного розвитку економіки, сталому використанні природних ресурсів, трансформації структури експорту, спрямованої на виробництво продуктів первинної переробки та надання послуг з високим ступенем доданої вартості, впровадження ідеології «зеленої» економіки.

Відмінними особливостями концепції та стратегії «зеленого» зростання ОЕСР [4] є усвідомлення того, що:

-природний капітал розглядається як фактор виробництва i продуктивний капітал, відновлення та нарощування якого потребує інвестицій;

-екологічна політика розглядається як інвестиційна політика, спрямована на підвищення ефективності використання природних ресурсів шляхом розвитку і використання новітніх ресурсо- та енергоефективних низьковуглецевих технологій.

-зелені види діяльності та екологічні інновації покликані сприяти структурній перебудові, підвищенню продуктивності праці, капіталу, використання ресурсів та підтримувати перехід на технології нової хвилі і модернізацію інфраструктури;

-тісний взаємозв'язок між економічною та екологічною політикою забезпечується шляхом використання таких інструментів як більш справедливе ціноутворення та оподаткування для стимулювання ресурсозбереження, уведення більш жорстких, але стимулюючих екологічних стандартів і технічних регламентів, реформування системи субсидій на енергоресурси, упровадження розширеної системи індикаторів для оцінки результативності дій та прийняття полі- 
тичних рішень у цих напрямах.

Міжнародні організації докладають зусиль до впровадження ідеології «зеленого» зростання шляхом впровадження нових ресурсно-ефективних та більш чистих технологій; підвищення ефективності сільського та лісового господарства; покращання екологічної інфраструктури; корекції суспільних цінностей та екологізованої поведінки людей ; пошуку рішень щодо кліматичної політики; створення зелених робочих місць.

Метою даного дослідження $€$ визначення векторів сучасної екологічної політики України у відповідності до глобальних екологічних та кліматичних викликів та їі курсу щодо приєднання до Європейського Союзу.

Виклад основного матеріалу. На сьогодні питання обґрунтування вибору шляхів суспільно-політичного та економічного розвитку України є надзвичайно актуальними. При плануванні та здійсненні економічних та соціальних реформ необхідно передбачати та оцінювати їх вплив на умови та рівень життя населення і наслідки для майбутніх поколінь. Оновлення завдань Цілей Розвитку Тисячоліття [5] має стати поштовхом для цілеспрямованого вдосконалювання регулюючих механізмів, що розвинулися в ході трансформаційних зрушень в Україні з одночасним забезпеченням прав людини на екологобезпечне середовище.

Оскільки економіка України енергоємна та ресурсовитратна, постає завдання щодо забезпечення її конкурентоспроможності. Неузгодженість темпів економічного розвитку і вимог екологічної безпеки, домінування ресурсномістких галузей, велика частка ресурсо- і енергоємних застарілих технологій, сировинна орієнтація експорту, відсутність гуманістичних цінностей серед пріоритетів розвитку, а також культури праці і споживання призводять до поглиблення кризи в економіці, погіршення стану довкілля, що створює реальну загрозу життю і діяльності сучасних і майбутніх поколінь.

Наразі національна економіка потребує адаптації до умов екологічно-безпечної конкуренції на регіональних та глобальних ринках, що передбачає підвищення ефективності виробництва, пристосування структури національної економіки до глобальної конкуренції, підвищення рівня наукомісткості та інноваційності економіки, сприяння створенню екологоорієнтованих видів бізнесу, запровадженню міжнародних екологічних стандартів виробництва тощо.

Вектор «зеленої» економіки потребує узагальнення теоретичних поглядів та положень до законодавчо обґрунтування розвитку екологічної політики як на національному, так і на державному рівнях. При цьому міжнародна співпраця повинна стати домінантною 
рисою і рушійною силою екологічних реформ у просторовому вимірі. В зв'язку з цим необхідно і надалі поширювати та пропагувати ідеологію розвитку «зеленої» економіки у трансформації суспільних відносин в Україні, а також імпоементувати прогресивний досвід ЄС.

У 2012 p. Європейська Комісія представила нову Програма дій Союзу з охорони навколишнього середовища до 2020 року «Жити добре, в межах можливостей нашої планети», яка буде керівною для екологічної політики на період до 2020 року. Вона спрямована на підвищення екологічної сталості в Європі та перетворення ЄС у інклюзивну і сталу «зелену» економіку і, в тому числі включає підвищення ефективності діяльності ЄС щодо реагування на регіональні та глобальні екологічні та кліматичні виклики.

Формування доктрини «зеленої» економіки в контексті глобальних екологічних та кліматичних змін повинно розглядатися як систему довгострокових дій, що деталізує ресурсні можливості та обґрунтування вагомості «зеленого» зростання економіки України з одночасним формуванням сприятливого бізнес-середовища, як на державному, так і регіональному рівнях. Зазначена доктрина базується на аналізі можливостей більш ефективно використовувати наявні природні блага на принципах міжрегіональної (транснаціональної) кооперації і взаємної компенсації завданих збитків, а також більш ефективного використання резервів «зеленого» зростання. Впровадження обраних заходів повинно сформувати сталу економічну систему, орієнтовану на забезпечення «зеленого» вектору розвитку економіки країни та її регіонів.

Розглядаючи інституційний зріз проблеми, слід, перш за все, доцільно зосередитися на таких складових як законодавчонормативна, яка охоплює площину правових інститутів: інфраструктурна (мережа інституційних структур, які полегшують перехід «коричневої» моделі економіки до «зеленої»(ресурсоефективної та низько вуглецевої); комунікаційна (Інформаційно-методичне супроводження, яке сприяє результативності реформ та посиленню рівня інформованості).

Найбільш значущі управлінські рішення останнього часу - розробка та затвердження планів імплементації кожної конкретної директиви та регламенту. Важливим елементом планів імплементації, поряд із коротким описом стану впровадження та метою і завданнями плану, $є$ перелік нормотворчих, інституційних, організаційних та координаційних заходів. Наразі основна увага зосереджена на імплементації Директиви 2010/75/ЄС про промислові викиди (всеохоплююче запобігання і контроль забруднень), що має два основні компоненти - скорочення викидів від великих спалювальних установок 
та впровадження інтегрованого дозволу. У сфері зміни клімату важливою подією стала ратифікація Україною Паризької угоди та затвердження Концепції реалізації державної політики у сфері зміни клімату на період до 2030 року, метою якої $€$ вдосконалення державної політики у сфері зміни клімату для досягнення сталого розвитку держави, створення правових та інституційних передумов для забезпечення поступового переходу до низьковуглецевого розвитку за умови економічної, енергетичної та екологічної безпеки і підвищення добробуту територіальних громад.

Проте, є сенс взяти на озброєння сучасні підходи індустріально розвинених країн до інтегрованого вирішення економічних, соціальних та екологічних питань в стратегіях переходу до «зеленого» росTy.

Існуючі вже стратегічні документи та регламенти міждержавного рівня в напрямі поширення ідеології «зеленої» економіки- Стратегія «Європа - 2020», Хартія Землі, Глобальний зелений новий курс Екологічної програми ООН (ЮНЕП), рамкова Стратегія зеленого зростання Організації Економічного Співробітництва та Розвитку (ОЕСР), Інноваційна стратегія Світового банку та організації ООН з промислового розвитку (ЮНІДО), «Майбутнє, якого ми хочемо» - підсумковий документ Конференції ООН Ріо+20 та інші направлені на забезпечення підтримки країн до переходу на ресурсоефективну та низьковуглецеву економіку, розвиток якої базується на інноваційній основі та впровадженні більш чистих технологій.

Тому можна констатувати, що зміна ідеології в сфері державного екологічного управління викликана зростаючими потребами суспільства в екологічному та чистому навколишньому природному середовищі.

Постійне вдосконалення системи екологічного управління $є$ однією з вимог міжнародної та європейської системи стандартизації екологічного управління. Для державної системи екологічного управління це означає іï функціональне розширення й системнометодологічне поглиблення. Йдеться не тільки про охоронні функції, а й про освоєння функцій гармонізації. Отже, системнометодологічне поглиблення - це освоєння нових сучасних механізмів екологічного управління, їх підпорядкування природному механізмові біотичного регулювання навколишнього природного середовища і принципам збалансованого розвитку.

Інтеграція екологічної складової в секторальних політиках. Одним з пріоритетних завдань «зеленого зростання України стає запровадження нових принципів та ефективних заходів, спрямованих на інтеграцію екологічної складової в усі галузі економіки. При цьому 
співпраця між Україною та ЄС у рамках Угоди про асоціацію відіграє визначальну роль для успіху реформи екологічного врядування, яка вимагає докорінних змін у підходах до планування політики, розробки та прийняття законодавства, трансформації природоохоронних інститутів та способу управління, адекватних ресурсів та підтвердження політичних зобов'язань, щоб зробити питання охорони довкілля та зміни клімату пріоритетними у порядку денному країни.

Глава 6 Угоди «Навколишнє природне середовище» окреслює основні напрями співпраці для змін у системі екологічного врядування (Ст. 360-363, 365, 366) і є ключовою для розуміння стратегічної суті екологічних реформ [6].

Таким чином, питання розподілу повноважень природоохоронних органів на національному, регіональному та місцевому рівнях знаходиться в стані трансформації. Що стосується процедури прийняття рішень та їх виконання для належного екологічного врядування, на особливу увагу заслуговує проблема ефективного залучення громадськості, що потенційно $є$ потужним механізмом інтеграції екологічної політики до галузевих політик та інструментом покращення якості державних рішень. Як зазначено в Доповіді Платформи громадянського суспільства Україна-ЄС( Брюссель, 18 травня 2017 р.), такі діалоги поки що відбуваються несистемно і потребують кращого структурування та координації з боку Мінприроди [6].

При цьому доцільно взяти на озброєння сучасні підходи індустріально розвинених країн до інтегрованого вирішення економічних, соціальних та екологічних питань в стратегіях переходу до «зеленого» росту. Необхідність в такій системі підтверджується логікою сучасних реформ в Україні. Все це потребує від державних інституцій, посадових осіб, усього суспільства особливого розуміння та дій щодо застосування екосистемного підходу в практиці державного планування й управління, національного розвитку та життєдіяльності.

Резюмуючи вищезазначене, можна стверджувати, що українську модель «зеленої» економіки необхідно будувати з урахуванням не лише національних і регіональних особливостей, а й світового та європейського досвіду.

Якщо предметно говорити про екологічну модернізацію, то перш за все мова йде про зміну суспільних інтересів в напрямі пошуку інноваційних шляхів екологоорієнтованого розвитку. Це не лише розвиток науки та ії прикладних досліджень задля оновлення засобів виробництва на основі найсучасніших технологій, що супроводжується проникненням новітніх розробок науки та техніки у сферу комунікації (інформаційне суспільство) та інші сфери життя, а й наслідки проведення комплексних інституційних реформ та транс- 
формація еколого-економічних відносин.

Інструментом соціально-екологічної модернізації $€$ здійснення цілої низки реформ, спрямованих на запровадження найбільш ефективних принципів, механізмів та форматів екологічного управління соціально-економічними процесами в країні. При цьому безумовним імперативом суспільства має стати практична реалізація моделі сталого розвитку та зеленої економіки, що забезпечує інтегральне поєднання економічної ефективності, соціальної справедливості, ресурсної збалансованості та екобезпеки.

Відповідальність України, яка взяла на себе виконання міжнародних зобов'язань щодо реалізації принципів сталого розвитку, розповсюдження та впровадження в систему державного та регіонального управління напрямів та механізмів, які сприяють досягненню вимог «зеленої» економіки, обумовлює їх практичне втілення.

Що стосується інших двох складових інституційного забезпечення розвитку «зеленої» економіки - інфраструктурної та комунікаційної, то, безперечно їх формування ще недостатнє, оскільки на сьогодні в Україні на державному рівні ще не в повній мірі реалізується ідеологія «зеленого» зростання, хоча законодавчо ці механізми дещо підкріплені за рахунок загальноєвропейських документів та існуючої практики. На жаль, в країні недостатньо відповідних інституцій( Агенств, консалтингових центрів тощо), які б допомагали забезпечувати прогрес в цій площині. Однією з причин $є$ те, що Україна не задекларувала своє бажання розробити власний Глобальний Зелений Курс.

Між тим значну допомогу у здійсненні екологічної реформи надають регіональні проекти технічної допомоги за фінансування ЄC та країн-членів: EAP GREEN, SEIS, CLIMA EAST, EUWI II, Emerald Network, які спрямовуються на 6 країн Східного Партнерства. Варто відзначити, що Мінприроди координує діяльність щодо цих проектів в Україні і займає активну позицію у плануванні та впровадженні «зелених» програм розвитку.

Висновки. На сьогодні ідеологія розвитку «зеленої» економіки в контексті подолання наслідків глобальних кліматичних змін $€$ основною парадигмою трансформаційних зрушень у сучасному суспільстві. Хоча перехід до «зеленої» економіки вимагає значних інвестицій, їх залученню мають сприяти продумана державна політика та інноваційні механізми фінансування. Швидке зростання ринків капіталу, вдосконалення ринкових інструментів, а також формування відповідного інституційного середовища відкривають шлях до великомасштабного фінансування глобального переходу економіки на «зелені» рейки. 
При цьому визначення та активна реалізація пріоритетів інноваційного розвитку України в «зеленому» форматі мають сприяти зміцненню на світовому та європейському рівнях іміджу України як держави з екологоорієгтованою політикою. Наявні політичні ініціативи на міжнародному та національному рівні на підтримку вектору «зеленого» зростання свідчать, що в Україні досягнута певна динаміка озеленення національної економіки.

Однак, незважаючи на це, до цього часу не затверджено проект Концепції «зеленої» економіки та не розроблено відповідно до глобальних екологічних та кліматичних викликів Стратегію низьковуглецевого розвитку України на довгострокову перспективу. Крім того, враховуючи процеси децентралізації, потребує значних доповнень нормативно-правова база щодо визначення якісних та кількісних індикаторів «зеленої» економіки.

При цьому всі реформи, які направлені на наближення законодавства України до права ЄС в сфері охорони довкілля носять регіональний характер, особливо беручи до уваги процес децентралізації. Це передбачає широке залучення місцевих органів влади до вироблення політики та законодавства з тих питань, щодо яких в них є повноваження. Імплементація екологічної складової Угоди про асоціацію між Україною та ЄС має бути підпорядкована досягненню цілей реформування екологічного врядування з метою покращання стану та підвищення ступеню захисту довкілля України в врахуванням глобальних кліматичних змін.

Тому Україна повинна якомога щільніше наблизитись до європейського формату та забезпечити максимально повну реалізацію економічного потенціалу держави у стратегії формування високопродуктивної еколого-економічної системи, що можливо лише за рахунок реалізації курсу «зеленої» економіки на державному рівні.

1. За підсумками року (Інтерв'ю президента НАН України академіка Б. Є. Патона). Вісн. НАН України. 2013. № 1. С. 3-10. 2. Національна доповідь «Цілі сталого розвитку: Україна» URL: http://un.org.ua/images/SDGs_NationalReportUA_Web_1.pdf (дата звернення: 10.12.2018). 3. Ідеологія "зеленого" зростання в системі національної економіки (теорія, інституційний базис, інструменти) : колект. монографія / Т. П. Галушкіна та інші. Одеса : НАН України, Ін-т проблем ринку та екон.екол. дослідж., 2014. 379 с. 4. Навстречу “зеленой” экономики: пути к устойчивому развитию и искоренению бедности - обобщающий доклад для представителей властных структур. Доклад ЮНЕП. 2011 p. URL: www.unep.org/greeneconomy (дата звернення: 10.12.2018). 5. Цілі Розвитку Тисячоліття - Україна : національна доповідь. Міністерство економіки України. Київ, 2010. 108 с. URL: http://network.org.ua/wp- 
content/uploads/2017/03/Zili-rozvytky-tysacholittya-Ukraina-2010-

nazionalna-dopovid.pdf (дата звернення: 10.12.2018). 6. Охорона довкілля в Угоді про асоціацію між Україною та ЄС. Доповідь Платформи громадянського суспільства Україна-ЄС. Брюсель, 18 травня, 2017p. 85 с. URL: https://drive.google.com/file/d/0ByGg_NFTRLvjeDA2R2ZKbThKRDA/view (дата звернення: 10.12.2018).

\section{REFERENCES:}

1. Za pidsumkamy roku (Interviu prezydenta NAN Ukrainy akademika B. le. Patona). Visn. NAN Ukrainy. 2013. № 1. S. 3-10. 2. Natsionalna dopovid «Tsili staloho rozvytku: Ukraina» URL: http://un.org.ua/images/SDGs_NationalReportUA_Web_1.pdf (data zvernennia: 10.12.2018). 3. Ideolohiia "zelenoho" zrostannia $v$ systemi natsionalnoi ekonomiky (teoriia, instytutsiinyi bazys, instrumenty) : kolekt. monohrafiia / T. P. Halushkina ta inshi. Odesa : NAN Ukrainy, In-t problem rynku ta ekon.ekol. doslidzh., 2014. 379 c. 4. Navstrechu "zelenoi" ekonomiki: puti k ustoichivomu razvitiiu i iskoreneniiu bednosti - obobshchaiushchii doklad dlia predstavitelei vlastnykh struktur. Doklad YuNEP. 2011 r. URL: www.unep.org/greeneconomy (data zvernennia: 10.12.2018). 5. Tsili Rozvytku Tysiacholittia - Ukraina : natsionalna dopovid. Ministerstvo ekonomiky Ukrainy. Kyiv, 2010. 108 s. URL: http://network.org.ua/wpcontent/uploads/2017/03/Zili-rozvytky-tysacholittya-Ukraina-2010-

nazionalna-dopovid.pdf (data zvernennia: 10.12.2018). 6. Okhorona dovkillia v Uhodi pro asotsiatsiiu mizh Ukrainoiu ta YeS. Dopovid Platformy hromadianskoho suspilstva Ukraina-YeS. Briusel, 18 travnia, 2017r. 85 s. URL: https://drive.google.com/file/d/0ByGg_NFTRLvjeDA2R2ZKbThKRDA/view (data zvernennia: 10.12.2018).

Рецензент: к.е.н. професор Ковшун Н. Е. (НУВГП)

Halushkina T. P., Doctor of Economics, Professor (State Ecological Academy of Postgraduate Education and Management, Kiev), Zhemba A. I., Candidate of Economics (Ph.D.), Associate Professor (National University of Water and Environmental Engineering, Rivne), Sernytska K. V., Post-graduate Student (State Ecological University, Odessa)

\section{ECOLOGICAL POLICY OF UKRAINE IN THE CONTEXT OF GLOBAL CLIMATIC CHALLENGES}

The article discusses areas of improvement of environmental policy in accordance with international law and modern global challenges. It has been substantiated that the introduction of environment-friendly measures should form a sustainable economic system, focused on 
ensuring the "green" vector of development of the economy of the country and its regions, taking into account global climate change. It is proved that at the present stage it is important to ensure the fullest possible realization of the economic potential of the state on the path to the implementation of international requirements, which is possible only through the implementation of the green economy course at all hierarchical levels.

Keywords: environmental policy, green economy, environmental and climate change, ecosystem approach, environmental management.

Галушкина Т. П., д.э.н., профессор (Государственная экологическая академия последипломного образования и управления, г. Киев), Жемба А. И., к.э.н., доцент (Национальный университет водного хозяйства и природопользования, г. Ровно), Серницкая К. В., аспирант (Государственный экологический университет, г. Одесса)

\section{ЭКОЛОГИЧЕСКАЯ ПОЛИТИКА УКРАИНЫ В КОНТЕКСТЕ ГЛОБАЛЬНЫХ КЛИМАТИЧЕСКИХ ВЫЗОВОВ}

В статье рассматриваются направления совершенствования экологической политики в соответствии с международным законодательством и современными глобальными вызововами. Обосновано, что внедрение экологобезопасных мероприятий должно сформировать устойчивую экономическую систему, ориентированную на обеспечение «зеленого» вектора развития экономики страны и ее регионов с учетом глобальных климатических изменений. Доказано, что на современном этапе важно обеспечить максимально полную реализацию экономического потенциала государства на пути имплементации международных требований, что возможно только за счет реализации курса «зеленой» экономики на всех иерархических уровнях.

Ключевые слова: экологическая политика, зеленая экономика, экологические и климатические изменения, экосистемный подход, экологическое управление. 